\title{
Studia
}

SYNCHRONICZNE I DIACHRONICZNE ASPEKTY BADAŃ POLSZCZYZNY

www.wnus.edu.pl/sj | DOI: 10.18276/sj.2019.18-08 | 109-123

\section{DANUTA KOWALSKA}

ORCID: 0000-0002-5550-5650

Uniwersytet Łódzki, Łódź

danuta.kowalska@uni.lodz.pl

Magdalena Pietrzak

ORCID: 0000-0002-2136-356X

Uniwersytet Łódzki, Łódź

magdalena.pietrzak@uni.lodz.pl

\section{Od Listów z podróży do Ameryki (1876-1878) do Listów z Afryki (1891-1892), czyli o ewolucji warsztatu pisarskiego Henryka Sienkiewicza}

\author{
Słowa kluczowe \\ idiolekt, język artystyczny, Henryk Sienkiewicz, listy z podróży \\ Keywords \\ idiolect, artistic language, Henryk Sienkiewicz, travel letters
}

W opracowaniach poświęconych warsztatowi pisarskiemu Henryka Sienkiewicza badacze wielokrotnie akcentowali znaczenie, jakie dla rozwoju artystycznego autora Trylogii miały jego dwie pozaeuropejskie podróże: odbyta w latach 1876-1878 wyprawa do Ameryki Północnej oraz zorganizowana kilkanaście lat później wyprawa myśliwska do Afryki. Relacje z obu wyjazdów były zamieszczane w formie listów na łamach ówczesnych gazet: amerykańska korespondencja pisarza publikowana była w „Gazecie Polskiej” od 9 maja 1876 do 23 marca 1878 roku, afrykańskie wspomnienia ukazywały się na łamach „Słowa” od 31 stycznia 1891 do 27 lutego 1892 roku. Obie relacje doczekały się także osobnych książkowych wydań: w roku 1880 ukazały się Listy z podróży do Ameryki, zaś w roku 
1893 światło dzienne ujrzała dwutomowa edycja Listów z Afryki. Jak zauważa Jerzy Roman Krzyżanowski:

W twórczości każdego niemal wybitnego pisarza dają się wyróżnić okresy, które biografowie i historycy literatury przywykli określać jako lata kształtowania się pełnej i dojrzałej fazy pisarstwa, [...] niejednokrotnie zresztą związanych z dojrzałością typu pozaliterackiego - ukształtowaniem światopoglądu, postawy moralnej czy zdecydowanego obrania drogi twórczości artystycznej. [...] Przykład Sienkiewicza tezy powyższe potwierdza ponad wszelką wątpliwość, przy czym za okres kształtowania się dojrzałej formy jego sztuki literackiej można przyjąć daty wyznaczone latami 1876-78, a więc lata pobytu pisarza w Ameryce ${ }^{1}$.

Pobyt na drugiej półkuli okazał się dla Litwosa wyjątkowo płodny - zarówno pod względem literackim, intelektualnym, jak i artystycznym. Nie tylko zapoczątkował entuzjastyczny odbiór jego twórczości, lecz także gruntownie zmienił jego pozycję w środowisku literackim Warszawy i w całym kraju. Listy z Ameryki pobiły absolutny rekord poczytności, od nich też rozpoczyna się wielka pisarska kariera Sienkiewicza. Walery Przyborowski z zazdrością komentował po latach: „Przestrzenie olbrzymie, wielka atmosfera, «daleki Zachód», rozparł mu piersi szeroko, zaprawił mu wzrok do spoglądania w dal nieskończoną, tak że wrócił jako talent niepospolity, pierwszorzędny”2. Andrzej Stawar podkreślał, że okres pobytu Sienkiewicza w Ameryce wyczulił w nim zmysł spostrzegawczości:

Pobyt za granicą, zetknięcie się z różnymi środowiskami rozwinęło środki pisarskie, rozszerzyło spostrzegawczość. Długie miesiące pobytu w stepie czy w puszczy, z dala od większych skupisk ludzkich, wyrobiły w Sienkiewiczu wyjątkowe odczucie pejzażu. Sienkiewicz wyrażał niekiedy żal, iż nie został malarzem - malarstwo uważał za sztukę bardziej bezpośrednio przemawiającą do odbiorcy niż literatura. Właśnie w tym okresie dar malowania rozwinął się w pisarzu w sposób wyjątkowy ${ }^{3}$.

Również dla Zdzisława Najdera opisy przyrody należały do największych osiągnięć artystycznej prozy Listów z podróży do Ameryki. Według badacza nikt przed Sienkiewiczem nie tworzył w prozie tego typu deskrypcji na tak wysokim poziomie: „Najcenniejszym osiągnięciem prozy Listów są opisy przyrody: wschody i zachody słońca, puszcza w nocy, dolina górska w świetle dnia, gorący wiatr. Literatura polska miała dotychczas

\footnotetext{
${ }^{1}$ Jerzy Roman Krzyżanowski, „Znaczenie Listów z podróży do Ameryki”, w: tenże, Legenda Samosierry i inne prace krytyczne (Warszawa: Czytelnik, 1987), 25.

2 [Walery Przyborowski], Stara i młoda prasa. Przyczynek do historii literatury ojczystej (1866-1872). Kartki ze wspomnień eksdziennikarza (Petersburg: Księgarnia K. Grendyszyńskiego, 1897), 131.

${ }^{3}$ Andrzej Stawar, Pisarstwo Henryka Sienkiewicza (Warszawa: Państwowy Instytut Wydawniczy, 1960), 23-24 [podkr. - D.K, M.P.].
} 
wspaniałe obrazy takich zjawisk, ale w poezji, w prozie nikt przed Sienkiewiczem nie dał ich tyle i na takim poziomie"s.

Z równie entuzjastycznymi ocenami krytyków spotkały się wydane 14 lat później Listy z Afryki. Józef Weyssenhoff zauważał, że wielki urok i artystyczna wartość książki leżą w nowym sposobie kreślenia krajobrazów, w opisach przyrody, które, zdaniem badacza, należą do najlepszych w literaturze europejskiej5. Krytyk w taki oto sposób dzielił się z czytelnikami wrażeniami po lekturze Listów:

Płynie to swobodnie, bez żadnej pretensji, jak jakie przyjacielskie zawierzenie, ubrane w humor i poezję. I chodzisz tak sobie z autorem po Afryce, jak prowadzony za rękę, trochę się uczysz, a dzielisz nie tylko jego wewnętrzniejsze nastroje, ale prawie i przyjemności. [...] Kto jest smakoszem, będzie ślinkę połykał, czytając pochwałę afrykańskich owoców; kto myśliwy, przebędzie z autorem prawdziwie łowieckie emocje przy opisach polowań na hipopotamy [...]. Ale co najważniejsze, że każdy, choć nie smakosz, zrozumie przyjemność jedzenia; choć nie myśliwy, odczuje urok poetycznej awantury, a każdemu zrobi się gorąco przy opisie skwaru6

Według badacza afrykańskie listy jako literacki opis podróży są przede wszystkim popisem stylu i przewyższają pod względem artystycznym amerykańską korespondencję pisarza:

Listy z Ameryki były przez lat kilkanaście ulubionym wzorem opisów podróży. Dzisiaj jednak prześcignięte zostały przez samego ich autora i trzeba je odczytać, żeby zobaczyć, jakim ogromnym wzlotem poszedł wyżej talent Sienkiewicza-pejzażysty. [...] afrykańskie opisy przyrody są tak dalece od tamtych wyższe i bardziej przejmujące, że musi w tym tkwić zasadnicza prawie różnica. Nie mówiąc już o bogactwie wyrażeń i dobitności zdań, pozornie bardzo prostych, a tak dobranych i dźwięcznych, że zadawalniają słuch i umysł od razu, można powiedzieć - ostatecznie - trudno nie zauważyć nacisku, jaki Sienkiewicz w swych opisach podróży do Afryki kładzie na koloryt, na cechy subtelne, a specjalnie uderzające. Sienkiewicz wraża dzisiaj bardziej krajobrazy w uczucie, niż je szczegółowo przekazuje pamięci czytelnika?

Podobną opinię pół wieku później sformułował Zdzisław Najder: ,jeśli mistrzostwem stylu Listy z Afryki biją amerykańskie korespondencje Sienkiewicza, to znowu Listy z podróży do Stanów Zjednoczonych górują zdecydowanie młodzieńczą brawurą i żywością

\footnotetext{
${ }^{4}$ Zdzisław Najder, „O Listach z podróży do Ameryki Henryka Sienkiewicza”, Pamiętnik Literacki, 1 (1955): 116-117.

${ }^{5}$ Por. Józef Weyssenhoff, „Henryka Sienkiewicza Listy z Afryki. 2 tomy. Nakładem Redakcji «Słowa» 1893”, Biblioteka Warszawska, 1 (1893): 376.

6 Tamże, 380-381.

7 Tamże, 383-384.
} 
akcji”" Najder wskazywał także na pewną cezurę, jaką jego zdaniem stanowią Listy z Afry$k i$ w artystycznym rozwoju Sienkiewicza: „To, co najcenniejsze w dziele Sienkiewicza, zawarło się między dwiema wielkimi podróżami. Listy z podróży do Ameryki Północnej zwiastują prawdziwy wybuch talentu, sygnalizują dojrzałość pisarza, gotowość do wielkich osiągnięć. Listy z Afryki mówią nam, że pisarz zdobył szczyt w swoim rozwoju, że wyżej już się nie wzbije" . Obaj badacze zgodnie podkreślali, że mistrzostwo Sienkiewicza uwidacznia się przede wszystkim w nowym sposobie kreślenia krajobrazów ${ }^{10}$, i że to mistrzostwo osiąga swój szczyt właśnie w Listach $z$ Afryki ${ }^{11}$. Tego rodzaju sądy, formułowane na podstawie wybiórczych i niejęzykoznawczych analiz, mają zazwyczaj ogólnikowy charakter i ograniczają się do konwencjonalnych sformułowań.

Celem niniejszego szkicu jest zatem analiza językowo-stylistyczna, zmierzająca do wskazania językowych wykładników wybranych cech stylowych warsztatu pisarskiego Henryka Sienkiewicza oraz wydobycia różnic w sposobie kreślenia przez niego krajobrazów w dwóch utworach reprezentujących ten sam gatunek literacki: Listach z podróży do Ameryki oraz Listach z Afryki ${ }^{12}$, a w konsekwencji potwierdzenia bądź zweryfikowania opinii wcześniejszych badaczy na temat zauważalnej ewolucji w warsztacie pisarskim Litwosa na przestrzeni kilkunastu lat. Analiza ma charakter wybiórczy i sondażowy. Podstawę materiałową stanowią tożsame pod względem tematycznym wypowiedzi deskryptywne, a mianowicie opisy zachodów słońca kreślone przez pisarza podczas amerykańskiej podróży i malowane czternaście lat później podczas afrykańskiego rejsu przez Zatokę Sueską. Oto one:

(1) Na pokładzie zmiana: słońce zachodzi. Niebieskie i białe światto dnia wsiaka w siebie stopniowo złoto i czerwoność; powietrze świeże, trochę słone, przejęte na wskroś zdrowym zapachem ropy morskiej. Ocean, który przez cały dzień byt bez zmarszczek, staje sie jeszcze gładszy. Po prostu-usypia. Nagle jednak to szklanne przezrocze zaczyna jakby pękać w długie rysy. [...] I znowu tylko widać gładka, spokojna toń. Żarłacze nie oddality sie jednak, wptynęty tylko na złoty, niezmiernie świetlny szlak, usłany przez zachodzace słońce na wodzie. Na szlaku tym nie możemy ich dostrzec, bo oczy nasze mruża się pod nadmiarem blasku. Ale słońce zajdzie wkrótce. Promienna jego głowa już tylko do połowy wyglada z wody. Po chwili już tylko złote warkocze leża na fali: głowa zasunęła się za toń daleka. Jeszcze minuta: słońce zaszło.

\footnotetext{
${ }^{8}$ Zdzisław Najder, „O Listach z Afryki Henryka Sienkiewicza”, Pamiętnik Literacki, 4 (1956): 348.

9 Tamże, 350.

${ }^{10}$ Weyssenhoff, „Henryka Sienkiewicza Listy”, 383; Najder, „O Listach z Afryki”, 345.

${ }^{11}$ Najder, „O Listach z Afryki”, 345.

12 Podstawą materiałową badań są następujące wydania tekstów: Henryk Sienkiewicz, Listy z Afryki (Warszawa: Państwowy Instytut Wydawniczy, 1949), dalej skrót: LA; Henryk Sienkiewicz, Listy z podróży do Ameryki (Warszawa: Państwowy Instytut Wydawniczy, 1986), dalej skrót: LAm.
} 
Co za cudowna chwila teraz! Szeroka smuga wody w kierunku stońca świeci jeszcze, lśni, błyszczy się, mieni i gra barwami, jakoby oświecona spod spodu. Ta droga złocista ginie na krańcu widnokregu w morzu z purpury. Nie umiem, nie umiem tego wszystkiego opisać! Mimo woli pytasz sie, czy ta droga nie prowadzi do jakiej krainy zaziemskiej, gdzie wszystko jest piękne, nieśmiertelne, gdzie mitość jest wieczna, gdzie poetyczna cisza i upojenie wiecznie panuja. Nie wstydzisz się marzeń i poetycznych uniesień. Chciałbyś płynać tam goniąc za świattem jak ptak. Wowych blaskach migaja jakieś wysepki.

- Co to za wysepki? - pytam majtka.

- Endżel Ailand (Angel Island), Anielska Wyspa.

I doprawdy, nie tylko wyspa, ale wszystko tam byto anielskie.

Co za przepych barw! Całe niebo płonie czerwono, druga zorza pali się w Oceanie. Czarne skaty nadbrzeżne, połyskujace wilgocia, wygladaja jakby oblane krwia. Mewy pławia się w świetle czerwonym. W tym wszystkim tkwi ogromna jakaś prostota. Na górze niebo, w dole morze, kawat skalistego brzegu i jeden okręt na niezmiernych przestrzeniach, jedna mała, czarna łupinka, i więcej nic. Bo też nie ma nic prostszego nad majestat.

Mijamy Endżel Ailand. Zorze gasna. Na purpurowe jeszcze, ale mroczace się już tło wychodzi jedna gwiazda, druga. Na przednim maszcie rysuje się $w$ sieci lin czarna postać majtka. Po chwili zapalają błękitna latarnię; maszyna świszcze, zawijamy do jakiegoś portu. Statek idzie bardzo powoli, ale coraz więcej skręca ku brzegom. Tymczasem zapada noc. Jeszcze raz stychać świstanie. Skały nadbrzeżne rozstępuja się nagle tworzac obszerna, lekko pochylona ku morzu dolinę, w której widać kępy drzew, jakby nasze dąbrowy; dalej białe domki, światła w oknach, spiczasta wieża rysująca się na mrocznym tle nieba, bliżej warf zbudowany z palów drewnianych, a na nim ludzie z latarniami.

(LAm 263-264)

(2) Widziałem tego dnia wspaniały zachód słońca. Ozłociło się morze, ziemia i powietrze, a cały widnokrag zdawat się płonać. Ta niezmierna, fantastyczna powódź blasków ma w sobie coś smutnego, może z tego powodu, że rozświeca pustkowie. $W$ chwile później zeszedtem, nie pamiętam po co, do salonu i miałem wrażenie, że widze pożar, tyle czerwonego światta wpływało przez zachodnie okna. Wszystko tam byto czerwone, jakby od bengalskiego ognia - i obrusy i ściany i lustra i twarz stewartów. Ale wszystko to trwało krótko. Mrok czynit się tak szybko, jakby ktoś ciemność przesiewat z olbrzymich sit, z nieba na ziemię. Potem niebo zgasło, morze stało się żelazne i statek zajaśniat nagle we wnętrzu elektrycznem świattem.

Po obiedzie wyszedłem znów na pokład. Noc! gwiazdy! Droga mleczna bardzo wyraźna, ale Wielka Niedźwiedzica daleko niżej nad horyzontem, niż u nas. Wiatr ciepły niesie widocznie dużo wilgoci, bo osadza słony smak na ustach. Fali wielkiej nie ma, ale morze „gada,“ jak mówia marynarze. Czasem téz zdaje się wzdychać. 
Poszedtem na sam tyt statku, za koło sternicze. Morze byto ciemne, ale w biatej miazdze szlaku, ciagnacego się za parowcem, potyskiwaty czasem jasno-błękitne gwiazdy, wyskakujace nagle z głębiny, mienity się pióra pawie, to znów skry czerwonawe. Szlak fosforyzuje w ten sposób co noc.

Powietrze po prostu przeczyste! Oddycha się tu petnymi piersiami. Jednostajny odglos niestrudzonej śruby i szum morza kołysza jakby do snu. Rozmyśla się i rozpamiętywa doskonale. Kto chce wrócić myśla w przeszlość, ten wróci - i zobaczy ja, jak żywa. Wśród tej nocy, wśród otoczenia bez ksztattów, wśród tego nieokreślonego smutku, którym przesiąnięta jest zawsze ciemność, człowiek przestaje być bryta, a zmienia się w myśl sama, która leci, gdzie chce i odtwarza, co chce: i drogie chwile i drogie twarze.

Analizując porównywane utwory, nie sposób nie zauważyć, że zamieszczone w nich opisy przyrody noszą wyraźne ślady stylu artystycznego, czyli zamierzonej kreacji artystycznej, polegającej na świadomym komponowaniu obrazów z elementów dobieranych pod kątem przydatności dla celów artystycznych. Jak trafnie zauważa Alina Ładyka, „każdy taki obraz ma odrębną strukturę, w której liczą się wszystkie szczegóły, i w każdym naczelną rolę odgrywa nastrój wywołany przemyślanym układem linii i barw, świateł i cieni, elementów ruchu lub stagnacji, a także rozmaitego typu doznań towarzyszących opisywanym zjawiskom"13.

Przyjrzyjmy się, w jaki sposób i za pomocą jakich środków stylistycznych Sienkiewicz opisuje zachodzące słońce nad Oceanem Spokojnym podczas amerykańskiej podróży. W deskrypcji uderza bezpośredniość doznań pisarza, wszechstronność uczuć i skojarzeń zmysłowych, a także jego wrażliwość na kolorystykę nieba i morza, zmieniającą się pod wpływem światła. Przeważają wrażenia wizualne związane z barwą i światłem, coraz bogatsze i różnorodniejsze, przede wszystkim zmienne w trakcie trwania zjawiska. Wrażenia kolorystyczne oddawane są za pomocą przydawek przymiotnych: niebieskie i biate światto dnia, złoty szlak, zlote warkocze, droga zlocista, światto czerwone, purpurowe tto; przydawek rzeczownych: morze z purpury; rzeczowników abstrakcyjnych: złoto 'kolor złoty', czerwoność; przysłówków: płonie czerwono; porównań barwnych: wygladaja jakby oblane krwia. Językowymi wykładnikami wrażeń wizualnych związanych ze światłem są rzeczowniki z pola światła: światto, blask (2); przymiotniki i imiesłowy przymiotne w funkcji przydawek: świetlny szlak, woda oświecona od spodu; czasowniki nazywające czynność wydzielania światła: świeci jeszcze, lśni, błyszczy się, mieni i gra barwami; płonać, palić się, połyskiwać, a następnie jego stopniową redukcją: zorze gasna. Widoczne jest mistrzostwo pisarza w operowaniu niezbyt licznym, ale zróżnicowanym funkcjonalnie i formalnie repertuarem określeń barwnych i świetlnych w kreacji świata przyrody. Opis w znacznym

${ }^{13}$ Alina Ładyka, Henryk Sienkiewicz (Warszawa: Państwowe Wydawnictwo „Wiedza Powszechna”, 1971), 106. 
stopniu przesycony jest sensualizmem. Sienkiewicz dzieli się z czytelnikiem także wrażeniami związanymi z działaniem receptorów węchu i smaku, co sprawia, że deskrypcja staje się jeszcze bardziej sugestywna: powietrze jest świeże, trochę słone, przejęte na wskroś zdrowym zapachem ropy morskiej. Większość połączeń frazeologicznych o charakterze epitetów i przydawek to połączenia dość typowe. Najczęściej nie pełnią one funkcji zdobniczej, lecz podkreślają istotną właściwość przedmiotu bądź zjawiska.

Prezentowany opis jest nie tylko plastyczny, obrazowy, ale widoczna jest w nim także dramaturgia, dynamika zachodzących kolejno zjawisk, co w dużej mierze wynika z nasycenia obrazu formami werbalnymi, zwłaszcza czasownikami ruchu, które w połączeniu z rzeczownikami z pola światła, a w dodatku zestawione szeregowo, sprawiają, że obraz pulsuje, drga i nieustannie się zmienia, co wpływa na jeszcze większe nasycenie obrazu światłem ${ }^{14}$ : Szeroka smuga wody w kierunku słońca świeci jeszcze, lśni, błyszczy się, mieni i gra barwami, jakoby oświecona spod spodu. Ta droga złocista ginie na krańcu widnokręgu w morzu z purpury.

Dynamizacji opisu służy także umiejętne operowanie czasem przeszłym i teraźniejszym (praesens historicum). Przeważają czasowniki niedokonane: zachodzić, wsiakać, stawać się, usypiać, świecić, lśnić, błyszczeć się, mienić, grać barwami, ginać, migać, płonać, palić się, pławić się gasną́, wychodzić, iść, skręcać, zapadać, rozstępować się oraz akcentujące początek jakiegoś procesu: zaczynać pękać. Formy czasu teraźniejszego służą unaocznieniu obrazu, sprawiają, że odbiorca staje się mimowolnym świadkiem obserwowanego zjawiska astronomicznego, które trwa i dzieje się na jego oczach. Z chwilą, gdy zmiany w obrazie słońca stają się bardziej dynamiczne, gdy słońce nagle zaczyna skrywać się za horyzontem, czasowniki występują w postaci dokonanej i są wyrażone w czasie przeszłym, który ma podkreślać gwałtowność, ulotność i krótkotrwałość zjawiska: głowa zasunęła się za toń daleka, słońce zaszło. Dramaturgię opisu wzmacniają wyrażenia temporalne: nagle, po chwili, wkrótce, jeszcze minuta, tymczasem, powoli.

Pisarz sięga także po środki metaforyczne, które służą plastyce wyrazu, przede wszystkim personifikacje: Promienna jego [słońca] głowa już tylko do połowy wyglada z wody. Po chwili już tylko złote warkocze leża na fali: głowa zasunęła się za toń daleka; przenośnie: niebo płonie, zorza pali się. Częste są animizacje: ocean usypia; wysepki migaja, skały rozstepuja się. Do utartych i pospolitych należy także konstrukcja porównawcza: skały wygladaja jakby oblane krwia, kępy drzew jakby nasze dąbrowy. Stosunkowo często sięga pisarz po poetyckie peryfrazy: ocean to niezmierna przestrzeń, szklane przezrocze, rozświetlony promieniami zachodzącego słońca jego fragment to złoty, niezmiernie świetlny szlak, złote warkocze, droga złocista; okręt to jedna mała, czarna łupina, niebo po zachodzie słońca nazwane jest mroczacym tłem.

\footnotetext{
${ }^{14} \mathrm{Na}$ ten fakt zwracała uwagę Agnieszka Szczaus, „Pola światła i cienia w Listach z podróży do Ameryki Henryka Sienkiewicza", Studia Językoznawcze. Synchroniczne i diachroniczne aspekty badań polszczyzny, 4 (2005): 361.
} 
Zauważalne jest także bogactwo językowe, a zwłaszcza posługiwanie się synonimią. Obok czasownika płonać mamy leksem palić, obok czasownika pływać występuje jego synonim pławić się, obok określenia maszyna świszcze pojawia się w kolejnym zdaniu zwrot słychać świstanie; woda pod wpływem słonecznego światła świeci się, lśni, błyszczy, mieni się, gra barwami, miga, połyskuje. Wymienione formy werbalne pisarz zestawia szeregowo, co potęguje wrażenie nasycenia obrazów nie tylko ruchem, lecz także światłem ${ }^{15}$. Ocean jest nazywany morzem, woda, ale także tonią. Sensualizmowi, jak również realizmowi opisu służą wrażenia akustyczne, które zostają przez Sienkiewicza uwypuklone w momencie, gdy zapadający zmrok ogranicza lub nawet uniemożliwia percepcję wzrokową. Ich językowym wykładnikiem są formy czasownikowe: maszyna świszcze, jeszcze raz słychać świstanie.

Większość wskazanych środków językowo-stylistycznych odnajdziemy także w deskrypcjach zawartych w afrykańskiej korespondencji pisarza. Także i tu zasadą porządkującą jest realizm przedstawienia, który wynika m.in. z dokładności i subtelności określeń, wpływającej na wyrazistość przedstawianych zjawisk. Również w tym opisie zauważalna jest wysoka frekwencja rzeczowników konkretnych, które bezpośrednio nazywają opisywane desygnaty: morze, ziemia, powietrze, widnokrag, obrusy, ściany, lustra, twarz stewardów, niebo, statek, gwiazdy. Wizualizacji opisywanych zjawisk służą przymiotniki w funkcji przydawek, wskazujące na istotne cechy opisywanych obiektów. Są to najczęściej zwyczajne, nawet banalne określenia wyrazowe. Dominują wrażenia wzrokowe związane z barwą i światłem, różnorodne i zmienne w trakcie trwania zjawiska, podkreślane przez odpowiednią leksykę, przymiotniki: czerwone światło, morze żelazne, morze ciemne, biała miazga szlaku, jasno-błękitne gwiazdy, pióra pawie, skry czerwone; rzeczowniki: pożar, blask, mrok, ciemność; czasowniki: rozświecać, płonać, ozłocić się, zgasnać, zajaśnieć, fosforyzować. Obok wrażeń wizualnych pojawiają się wrażenia związane z działaniem receptorów smaku (słony smak na ustach), dotyku (wiatr ciepty, dużo wilgoci). Nie brak także wrażeń audytywnych wprowadzanych za pomocą określeń o metaforycznym charakterze $\mathrm{z}$ pola semantycznego dźwięk, w tym form werbalnych: morze gada, morze wzdycha oraz nominalnych: jednostajny odgłos śruby, szum morza, cisza. Opis przesycony jest środkami metaforycznymi w stopniu znacznym, przede wszystkim personifikacjami: ozłociło się morze, ziemia i powietrze, widnokrag zdawat się płonać, światło wptywało przez okna, morze stało się żelazne, statek zajaśniat świattem, niebo zgasło, powódź blasków, gwiazdy wyskakuja z głębiny. Nie brak konstrukcji porównawczych ${ }^{16}$ : wszystko tam byto czerwone jakby od bengalskiego ognia, mrok czynit się tak szybko jakby ktoś ciemność przesiewat z olbrzymich sit, z nieba na ziemię; Wielka Niedźwiedzica daleko niżej nad horyzontem niż u nas, szum morza kołysze jakby do snu, zobaczyć przeszłość jak żywa. Częste są epitety

\footnotetext{
15 Tamże, 360.

${ }^{16}$ Konstrukcjom porównawczym w Listach z Afryki Henryka Sienkiewicza poświęcony jest artykuł: Danuta Kowalska, „Środki artystycznego obrazowania w Listach z Afryki Henryka Sienkiewicza”, Studia Językoznawcze. Synchroniczne i diachroniczne aspekty badań polszczyzny, 16 (2017): 151-158.
} 
rzeczownikowe: zachód słońca, powódź blasków, miazga szlaku, pióra pawie, odgłos śruby, szum morza. Uwagę zwraca także wysoka frekwencja form werbalnych (czasownikowych oraz imiesłowowych): ozłocić się, płonać, rozświecać, wpływać, czynić się, przesiewać, zgasnać, stać się, zajaśnieć, nieść, osadzać, gadać, wzdychać, połyskiwać, wyskakiwać, mienić się, fosforyzować, ciagnacy się, wyskakujacy, niestrudzony. Dynamizacji opisu służą określenia temporalne: krótko, szybko, chwile później, nagle oraz subtelne zmiany czasu przeszłego na czas teraźniejszy: niebo zgasło, morze stało się żelazne, statek zajaśniat wiatr niesie, morze gada, szlak fosforyzuje. Cechą charakterystyczną stylu w analizowanej deskrypcji jest bogactwo leksykalne, a zwłaszcza posługiwanie się synonimią i operowanie wyrazami bliskoznacznymi. Sienkiewicz z ogromnym wyczuciem różnicuje leksykę, subtelnie cieniując znaczenia: złocić się - mienić się - połyskiwać - fosforyzować; płonać rozświecać-zajaśnieć; gadać-wzdychać; rozmyślać - rozpamiętywać; ocean - pustkowie - morze-głębina; blask-światto-pożar-bengalski ogień-skry; mrok-ciemność-noc; widnokrag - horyzont; statek-parowiec.

Zestawiane deskrypcje mają jeszcze jedną wspólną cechę, mianowicie realistycznemu opisowi przyrody towarzyszą nastrojowe refleksje, odczucia i odautorskie rozważania natury filozoficznej, wywołane obserwowanym zjawiskiem, co sprawia, że mają one dwudzielną kompozycję. Jednak te refleksyjne fragmenty są konstruowane za pomocą odmiennych środków stylistycznych. W amerykańskiej korespondencji w tego typu nastrojowych opisach wewnętrznego stanu pisarza do głosu dochodzą emocjonalne, nierzadko konwencjonalne epitety, poetyzmy i elementy świata fantastyki: kraina zaziemska, wieczna miłość, poetyczna cisza, poetyczne uniesienia, wszystko jest piękne, nieśmiertelne. Także konstrukcje porównawcze mają poetycki charakter: gonić za świattem jak ptak. Charakterystyczne jest zwłaszcza nadawanie zjawiskom przyrody pewnych znamion nadprzyrodzoności:

Mimo woli pytasz się, czy ta droga nie prowadzi do jakiej krainy zaziemskiej, gdzie wszystko jest piękne, nieśmiertelne, gdzie miłość jest wieczna, gdzie poetyczna cisza i upojenie wiecznie panują. Nie wstydzisz się marzeń i poetycznych uniesień. Chciałbyś ptynać tam goniac za świattem jak ptak. (LAm 263)

W miejsce rzeczowników konkretnych pojawiają się określenia o charakterze abstrakcyjnym, zestawiane $\mathrm{w}$ postaci szeregowych skupień: poetyczna cisza $i$ upojenie; marzenia i poetyczne uniesienia. Wyraźnie zmienia się także jakość leksemów przymiotnikowych w funkcji przydawki: zamiast określeń inherentnych występują określenia o charakterze poetyckim, upiększające, wyolbrzymiające i nadające opisywanym zjawiskom jakieś szczególne znaczenie: wszystko jest piękne, nieśmiertelne. Są to zazwyczaj wyrażenia i zwroty już mocno wytarte, o podniosłym charakterze, co w efekcie wprowadza stylistyczny dysonans, zakłócając harmonię w obrębie całego opisu. O tym, że nie jest to zjawisko odosobnione i przypadkowe świadczy kolejny opis zachodu słońca przeżywany na amerykańskiej ziemi: 
Opartszy się o karabin, patrzyłem nieruchomo z pót godziny na owa cudna dolinę. Na krańcu widnokręgu szarzała niby mgła, niby chmura jakaśs sina, ale rozświecona purpura zachodu. Byt to „Pacyfik”, ojciec oceanów i mórz wszystkich. We wzgórzach sterczacych nad tumanem poznatem wyspy: Santa Catalina i Catalina-Harbor, które zwiedzałem, bawiąc jeszcze w Landing. Byt zachód stońca, a nad Oceanem rozlewat się drugi ocean purpury i złota na niebie. Na dolinie ubranej w królewskie kolory ujrzałem naprzód suche, piaszczyste a szerokie łożysko równoległej do gór rzeki Santa Ana. Dalej ciemne grupy drzew oznaczały Anaheim i Orange, a mniejsze grupy - farmy rozrzucone po całym stepie. Wszystko to leżało u moich nóg. Patrzyłem na wioski $i$ miasta, jak ptak z chmur. Powietrze tak byto przezroczyste, że ten ogromny szmat kraju leżał widny dla mego oka, jak na dłoni. Cisza była prawie niepokalana. Śliczny, pogodny zachód zdawat się nasycać wszystko nieporównana słodycza i różanym spokojem. Błogosławieństwo i ukojenie wielkie unosiło się nad krajem... Wówczas wezbrato mi serce, a na usta wybiegła mimo woli znana smutna piosenka:

U nas inaczej! inaczej! inaczej! (LAm 231)

Istotne dla wypowiedzi deskryptywnej elementy krajobrazu dolina i zachód słońca określane są za pomocą konwencjonalnych leksemów przymiotnikowych o ogólnym charakterze, które nie wskazują na żadną istotną cechę kryjącą się w desygnacie: cudna dolina; śliczny, pogodny zachód; nieporównana słodycz. W opisie spotykamy elementy sakralizacji związane z obecnością leksyki właściwej językowi religijnemu: taki charakter ma szereg nominalny błogosławieństwo i ukojenie ${ }^{17}$, słodycz i spokój, fraza: wezbrało serce, przymiotnik niepokalany wykorzystany w połączeniu wyrazowym z rzeczownikiem $c i$ $s z a$. Przejawem stylizacji na język biblijny jest postpozycyjny szyk przydawki w wyrażeniu ukojenie wielkie, być może także wykorzystywanie przymiotników o charakterze zaprzeczonym: nieporównany 'niezrównany, nie mający sobie równego, jedyny w swoim rodzaju, nieoceniony, znakomity, wyborny'18, niepokalany 'nieskalany, niesplamiony, czysty, bez skazy, bez zmazy, niewinny, dziewiczy'19. Poetycki charakter ma niewątpliwie wyrażenie różany spokój (różany 'koloru róży, różowy ${ }^{20}$ ). Przejawem pewnej egzaltacji i wielosłowia są także użyte zabiegi personifikacyjne i animizacyjne: błogosławieństwo i ukojenie unosiło się nad krajem, wezbrało serce, piosenka wybiegła na usta oraz poetyckie peryfrazy o konwencjonalnym charakterze: Pacyfik to ojciec oceanów i mórz wszystkich.

Określeń wykorzystujących konwencjonalne przymiotniki o charakterze ogólnym spotykamy w amerykańskich listach znacznie więcej, np. blogosławiony 'zbawienny,

\footnotetext{
${ }^{17}$ SW leksem błogosławieństwo definiuje jako 'stan błogi, błogość; królestwo boże, niebieskie, szczęśliwość wieczna' i opatruje kwalifikatorem przestarzały (SW I, 175), zaś leksem ukojenie - jako czynność od czasownika ukoić 'uspokoić, uśmierzyć, ułagodzić, uciszyć, utulić, ukołysać' (SW VII, 266).

18 SW III, 313.

19 Tamże, 310.

${ }^{20} \mathrm{SW} \mathrm{V}, 751$.
} 
nieoceniony'21: błogosławiona anaheimska dolina; niepokalany: przeszłość jak śnieg niepokalana, niepokalane istoty; cudny (7) 'piękny, cudowny, śliczny, prześliczny, czarowny, czarujący, zachwycający'22: cudna zieloność, cudna dolina, miejsca cudne, cudne miasto; śliczny (23) 'przepiękny, uroczy, pyszny, cudny, zachwycający; bardzo przystojny'23: śliczne miasto, śliczna noc, śliczna pogoda, śliczny kwiat, śliczna główka antylopy, śliczne sosnowe lasy, śliczne doliny, śliczne dąbrowy, śliczny klimat, ranek śliczny, śliczny krajobraz morski. Bardzo wysoką frekwencją odznacza się przymiotnik piękny (90) 'mogący zadowolić wymagania estetyczne, cudny, cudowny, śliczny"24: piękne zjawisko, piękna pogoda, piękna zielona barwa zęba, czas piękny, piękny poranek, piękne gwiazdy morskie, krajobraz piękny itp.

Afrykańskie listy cechuje zdecydowanie większa dyscyplina stylistyczna. Oczywiście zdarzają się emocjonalne przydawki: wspanialy zachód słońca, niezmierna, fantastyczna powódź blasków, ale nigdy nie pojawiają się w nadmiarze, raczej mają okazjonalny charakter.

Przymiotniki takie jak błogosławiony, niepokalany w ogóle nie występują, inne, takie jak cudny mają jednostkowe użycia, zdecydowanie mniejszy zakres użycia ma także przymiotnik piękny, który ma blisko pięć razy niższą frekwencję. Nastroje pisarza oddawane są w sposób bezpośredni, bez zbędnego upiększania, za pomocą prostych, zwyczajnych określeń, np. powódź blasków ma w sobie coś smutnego, nieokreślony smutek. Partie refleksyjne cechuje prostota językowych określeń, dzięki czemu są one bardziej wiarygodne i podporządkowane technice realistycznego opisu. Uwagę odbiorcy przyciągają precyzyjną, uporządkowaną budową składniową zdań, opartą na paralelizmie składniowym i różnego typu symetrycznych układach syntetycznych, semantycznych oraz fonicznych, które pozwalają uwypuklić pewne elementy treściowe wypowiedzi. W Listach z Afryki zwraca uwagę dbałość pisarza o składniową symetryczność członów, w których zachowuje się identyczny szyk składników, regularne powtarzanie wskaźników zespolenia, powtarzanie pewnych wyrazów bądź morfemów, które stają się dodatkowo czynnikiem rytmotwórczym²5:

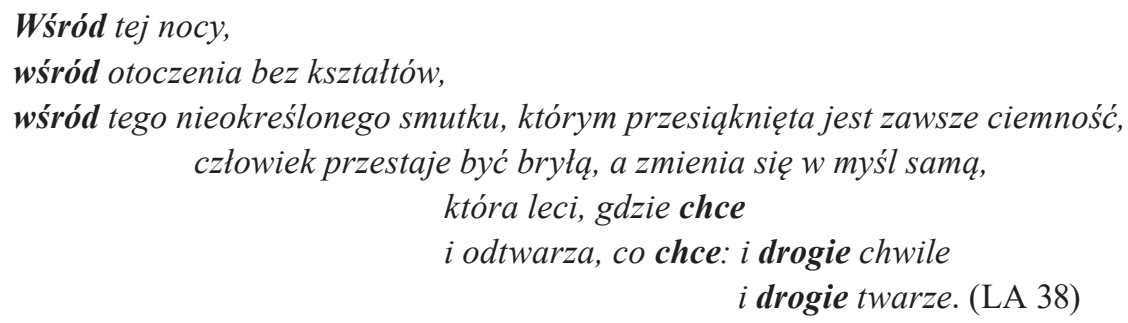

21 SW I, 175.

22 Tamże, 351.

${ }^{23}$ SW VI, 729.

24 SW IV, 180.

${ }^{25}$ Por. Danuta Kowalska, ,Język codziennej komunikacji w niecodziennym opracowaniu w Listach z Afryki Henryka Sienkiewicza”, Acta Universitatis Lodziensis. Folia Linguistica, 50 (2016): 169-171. 
Tego typu misterna, symetryczna budowa zdania pojawia się w wielu miejscach afrykańskich listów, także w nastrojowych opisach związanych z kontemplowaniem afrykańskiej przyrody. W połączeniu z prostotą języka, niewyszukanym, konkretnym, codziennym słownictwem wprowadza harmonię i wewnętrzny, semantyczny ład wypowiedzi:

Po prostu mówiąc ma się to niestychanie gnębiace wrażenie,

że z tego umarlego nieba nikt nie patrzy,

że wśród tych płowych piasków nikt nie styszy

$i$ że na pustyni próżno by rozpacz wołała o ratunek.

Stąd ucisk, stąd niepokój, stąd strach (LA 16).

Obserwacje poczynione na wyrywkowym materiale pokazują, że w zakresie opisywania zjawisk przyrody zasadnicze cechy warsztatu pisarskiego Henryka Sienkiewicza uformowane zostały już podczas spisywania wrażeń z amerykańskiej podróży, a następnie wykorzystane w późniejszych o kilkanaście lat Listach z Afryki. Do najbardziej typowych eksponentów stylu należą obrazowość, plastyczność oraz nastrojowość (wrażeniowość) opisów. Pisarz konsekwentnie dążył do wizualności obrazów, dbał o realizm przedstawienia. Opis Sienkiewiczowski jest więc nasycony elementami rzeczowymi, istotną rolę w jego budowie odgrywają określenia kształtu, barwy, światła i ruchu. Te cechy stylowe były konsekwencją zastosowania następujących językowych wykładników, które można uznać za charakterystyczne i stałe właściwości warsztatu pisarskiego Henryka Sienkiewicza ${ }^{26}$ :

1. Wysoka frekwencja rzeczowników konkretnych, które bezpośrednio nazywają opisywane desygnaty i które tak są dobierane, by najtrafniej oddać zjawisko przyrody ukazane na tle konkretnego krajobrazu: doliny, stepu, morza, oceanu itp. Są to najczęściej wyrazy, które - jak to określił Bolesław Prus - „bezpośrednio malują przedmiot czy własność i budzą w czytelniku nie tylko pojęcie, ale poczucie"27. Aleksander Wilkoń nazywa tę właściwość „funkcjonalnym podporządkowaniem znaku desygnatowi"28.

2. Wysoka frekwencja przymiotników i imiesłowów przymiotnych w funkcji przydawki.

3. Względny umiar w stosowaniu przymiotnych skupień, najczęściej mają one charakter dwójkowy, np. niebieskie i białe światło dnia; mała, czarna tupinka (LAm).

\footnotetext{
${ }^{26}$ Aleksander Wilkoń większość wskazanych w tym miejscu cech językowo-stylistycznych zaliczył do wyznaczników stylu realistycznego narracji Ogniem i mieczem. Por. Aleksander Wilkoń, O języku i stylu „Ogniem i mieczem” Henryka Sienkiewicza. Studia nad tekstem (Kraków: PWN, 1976), 53-59.

27 Bolesław Prus, „Ogniem i mieczem - powieść z dawnych lat Henryka Sienkiewicza”, Kraj, 28-30 (1884). Przedr. w: Tadeusz Bujnicki, „Trylogia” Henryka Sienkiewicza na tle tradycji polskiej powieści historycznej (Wrocław: Zakład Narodowy im. Ossolińskich, Wydawnictwo PAN, 1973), 195.

${ }^{28}$ Wilkoń, Ojęzyku, 54.
} 
4. Posługiwanie się epitetami rzeczownikowymi, np. ocean purpury, morze płomieni, morze dymów, blask jutrzenki, grzbiety fal, powódź kwiatów, btękit niebios, powódź blasków (LAm).

5. Obfitość form werbalnych, dynamizujących opis.

6. Operowanie formami temporalnymi, np. nagle, teraz, wkrótce, po chwili, jeszcze minuta, tymczasem (LAm); później, potem, nagle (LA).

7. Bogactwo leksykalne w zakresie synonimii oraz różnicowanie leksemów w obrębie jednego pola semantycznego, np. świecić się - lśnić - blyszczeć - mienić się - grać barwami - migać - połyskiwać (LAm); złocić się - mienić się - połyskiwać - fosforyzować; płonać - rozświecać - zajaśnieć; ocean - pustkowie - morze - głębina; blask - światło - pożar - bengalski ogień - skry; mrok - ciemność - noc (LA).

8. Obfitość konstrukcji porównawczych, np. skały wyglądaja jakby oblane krwia; kepy drzew jakby nasze dąbrowy (LAm); wszystko tam byto czerwone jakby od bengalskiego ognia; mrok czynit się tak szybko jakby ktoś ciemność przesiewat z olbrzymich sit, z nieba na ziemię (LA).

9. Metaforyzacja, a zwłaszcza personifikacja świata przyrody, np. Promienna jego [słońca] głowa już tylko do połowy wyglada z wody. Po chwili już tylko złote warkocze leża na fali: głowa zasunęta się za toń daleka (LAm); morze gada, morze wzdycha (LA).

10. Wysoka frekwencja leksyki związanej z opisywaniem własnych wrażeń i przeżyć, związanych z odczuwaniem świata natury, wprowadzanej konstrukcjami typu: czynić wrażenie, mieć wrażenie, robić wrażenie, sprawiać wrażenie, zostawić wrażenie, zdawać się, wrażenie powracało, naoczne wrażenia, niezatarte wrażenia, pierwsze wrażenie, miód wrażeń.

Ewolucja stylu Henryka Sienkiewicza dotyczy jedynie jakości zastosowanych środków językowych, przede wszystkim epitetów, które w późniejszej korespondencji są dobierane w sposób harmonijny i podporządkowany realizmowi opisu. Język cechuje umiar, widoczna jest większa jednolitość środków artystycznych oraz większa dyscyplina składniowa i dbałość o rytmiczną i foniczną stronę wypowiedzi. Autor dba, by cechy nastrojowe nie przesłaniały przedmiotu opisu, nieustannie zabiega, by swoją jakością i natężeniem były dostosowane do tematu ${ }^{29}$.

Badania warto poszerzyć i kontynuować, by poznać tajniki warsztatu pisarskiego Henryka Sienkiewicza. Wydaje się, że wdzięcznym materiałem do analiz jest zwłaszcza składnia, i to właśnie w jej zakresie da się zaobserwować największą ewolucję stylu Sienkiewicza. Warto podjąć trud badawczy, by się o tym przekonać.

\footnotetext{
${ }^{29}$ Na ten fakt zwracał uwagę Zdzisław Najder. Por. tenże, O Listach z podróży do Ameryki, 100-101.
} 


\section{Wykaz skrótów}

LA - Sienkiewicz, Henryk. Listy z Afryki. Warszawa: Państwowy Instytut Wydawniczy, 1949.

LAm - Sienkiewicz, Henryk, Listy z podróży do Ameryki. Warszawa: Państwowy Instytut Wydawniczy, 1986.

SW - Karłowicz, Jan, Adam Kryński, Władysław Niedźwiecki, red. Słownik języka polskiego. T. I-VIII. Warszawa 1900-1927.

\section{Bibliografia}

Kowalska, Danuta. „Język codziennej komunikacji w niecodziennym opracowaniu w Listach z Afryki Henryka Sienkiewicza". Acta Universitatis Lodziensis. Folia Linguistica, 50 (2016): 157-172.

Kowalska, Danuta. „Środki artystycznego obrazowania w Listach z Afryki Henryka Sienkiewicza”. Studia Językoznawcze. Synchroniczne i diachroniczne aspekty badań polszczyzny, 16 (2017): 149-162.

Krzyżanowski, Jerzy Roman. „Znaczenie Listów z podróży do Ameryki”. W: tenże, Legenda Samosierry i inne prace krytyczne. Warszawa: Czytelnik, 1987.

Kurkowska, Halina. ,Język publicystyki Sienkiewicza”. Poradnik Językowy, 1 (1957), 1-16.

Kurkowska, Halina, Stanisław Skorupka. Stylistyka polska. Zarys. Warszawa: Wydawnictwo Naukowe PWN, 2001.

Ładyka, Alina. Henryk Sienkiewicz. Warszawa: Państwowe Wydawnictwo „Wiedza Powszechna”, 1971.

Najder, Zdzisław. „O Listach z Afryki Henryka Sienkiewicza”. Pamiętnik Literacki, 4 (1956): 333-350.

Najder, Zdzisław. „O Listach z podróży do Ameryki Henryka Sienkiewicza”. Pamiętnik Literacki, 1 (1955): $54-122$.

Pietrzak, Magdalena. „Językowe sposoby opisywania (przybliżania) obcej rzeczywistości w Listach z podróży do Ameryki Henryka Sienkiewicza”. W: Wędrówka, podróż, migracja w języku i kulturze, red. Ewa Biłas-Pleszak, Joanna Przyklenk, Artur Rejter, Katarzyna Sujkowska-Sobisz. Katowice: Wydawnictwo Uniwersytetu Śląskiego, 2018, 345-359.

Prus, Bolesław. „Ogniem i mieczem - powieść z dawnych lat Henryka Sienkiewicza”. Kraj, 28-30 (1884). Przedr. w: Tadeusz Bujnicki, „Trylogia” Henryka Sienkiewicza na tle tradycji polskiej powieści historycznej. Wrocław: Zakład Narodowy im. Ossolińskich, Wydawnictwo PAN, 1973.

[Przyborowski, Walery]. Stara i młoda prasa. Przyczynek do historii literatury ojczystej (1866-1872). Kartki ze wspomnień eksdziennikarza. Petersburg: Księgarnia K. Grendyszyńskiego, 1897.

Seiffert, Irena. „Barwy Afryki w utworach Henryka Sienkiewicza”. W: Język pisarzy jako problem lingwistyki [Prace Językoznawcze 2], red. Tomasz Korpysz, Anna Kozłowska. Warszawa: Wydawnictwo Uniwersytetu Kardynała Stefana Wyszyńskiego, 2009, 265-285.

Seiffert, Irena, „Między bielą a czernią. Barwy w Listach z Afryki Henryka Sienkiewicza”. W: Henryk Sienkiewicz. Tradice - současnost - recepce, red. Mieczysław Balowski, Jana Raclavská. Ostrava: Ostravská Univerzita, Filozofická fakulta, 2006, 225-252.

Stawar, Andrzej. Pisarstwo Henryka Sienkiewicza. Warszawa: Państwowy Instytut Wydawniczy, 1960.

Szczaus, Agnieszka. „Pola światła i cienia w Listach z podróży do Ameryki Henryka Sienkiewicza”. Studia Językoznawcze. Synchroniczne i diachroniczne aspekty badań polszczyzny, 4 (2005): 355-364.

Weyssenhoff, Józef. „Henryka Sienkiewicza Listy z Afryki. 2 tomy. Nakładem Redakcji «Słowa» 1893”. Biblioteka Warszawska, 1 (1893): 375-384.

Wilkoń, Aleksander. O języku i stylu „Ogniem i mieczem” Henryka Sienkiewicza. Studia nad tekstem. Warszawa: PWN, 1976. 
Od Listów z podróży do Ameryki (1876-1878) do Listów z Afryki (1891-1892), czyli o ewolucji warsztatu pisarskiego Henryka Sienkiewicza

Streszczenie

Celem artykułu jest analiza językowo-stylistyczna, zmierzająca do wskazania językowych wykładników wybranych cech stylowych warsztatu pisarskiego Henryka Sienkiewicza oraz wydobycia różnic w sposobie kreślenia przez niego krajobrazów w dwóch utworach reprezentujących ten sam gatunek literacki: Listach z podróży do Ameryki oraz Listach z Afryki. Podstawę materiałową stanowią tożsame pod względem tematycznym wypowiedzi deskryptywne (opisy zachodów słońca). W toku analiz pokazuje się, że w zakresie opisywania zjawisk przyrody zasadnicze cechy warsztatu pisarskiego Henryka Sienkiewicza uformowane zostały już podczas spisywania wrażeń z amerykańskiej podróży, a następnie wykorzystane w późniejszych o kilkanaście lat Listach z Afryki. Ewolucja stylu Henryka Sienkiewicza dotyczy jedynie jakości zastosowanych środków językowych, przede wszystkim epitetów, które w późniejszej, afrykańskiej korespondencji dobierane są w sposób harmonijny i podporządkowany realizmowi opisu. Listy z Afryki wyróżniają się także większą dyscypliną składniową i dbałością o rytmiczną i foniczną stronę wypowiedzi.

From Listy z podróży do Ameryki ("Travel Letters from America”, 1876-1878) to Listy z Afryki ("Travel Letters from Africa", 1891-1892), or about the evolution of Henryk Sienkiewicz's writing manner

Sum mary

The article contains a linguistic and stylistic analysis that identifies linguistic exponents of selected stylistic features of Henryk Sienkiewicz's writing manner and detects the differences in the way he creates landscapes in his two works that represent the same literary genre: "Travel Letters from America" and "Travel Letters from Africa". The basis for the analysis are descriptive statements (descriptions of sunsets), identical from the thematic point of view. Thanks to the analysis it appears that Henryk Sienkiewicz's manner of describing nature was formed during his American trip, and later it was visible in his older "Travel Letters from Africa". The evolution of Henryk Sienkiewicz's style concerns only the quality of linguistic means, first of all epithets, which in his African letters were selected in a harmonious way and they were subordinated to the realism of the description. In "Travel Letters from Africa" the author maintains more syntactic discipline and cares more about the rhythmic and phonic aspects.

Cytowanie

Kowalska, Danuta, Magdalena Pietrzak. Od Listów z podróży do Ameryki (1876-1878) do Listów z Afryki (1891-1892), czyli o ewolucji warsztatu pisarskiego Henryka Sienkiewicza. Studia Językoznawcze. Synchroniczne i diachroniczne aspekty badań polszczyzny 18 (2019): 109-123. DOI: 10.18276/sj.2019.18-08. 